\title{
Seasonal variation in white spot syndrome virus-positive samples in broodstock and post-larvae of Penaeus monodon in Thailand
}

\author{
Boonsirm Withyachumnarnkul ${ }^{1, *}$, Vichai Boonsaeng ${ }^{1}$, Ranida Chomsoong ${ }^{2}$, Timothy W. Flegel ${ }^{1}$, \\ Sithisuk Muangsin ${ }^{3}$, Gary L. Nash ${ }^{1}$ \\ ${ }^{1}$ Centex Shrimp, Chalerm Prakiat Building, Faculty of Science, Mahidol University, Rama 6 Road, Bangkok 10400, Thailand \\ ${ }^{2}$ Department of Anatomy, Faculty of Medicine, Chiengmai University, 239 Huay Kaew Road, Chiengmai 50200, Thailand \\ ${ }^{3}$ Phuket Aquaculture R\&D Co. Ltd., 35/5 Mo 1, Thepratan Road, Phuket 83000, Thailand
}

\begin{abstract}
Records of PCR test results for white spot syndrome virus (WSSV) were reviewed in Thailand from 1998 to 2000 for wild Penaeus monodon broodstock purchased by hatcheries and for post-larvae (PL) brought by farmers to diagnostic laboratories for testing. Samples for PCR comprised DNA extracts from the last pleopod dissected from broodstock females after the first spawning and DNA extracts from whole, homogenized PL. There was a consistent pattern of fluctuation in percentage of WSSV-positive broodstock and PL. In broodstock, the fluctuation pattern was similar each year, with a low percentage ( 0 to $6 \%$ ) from January to May and a higher percentage ( 6 to $18 \%$ ) for the rest of the year, with a peak from September to November. The fluctuation pattern for PL was similar but offset with peaks and troughs occurring approximately 2 mo after those for the broodstock. The peak percentages of broodstock-positive samples were roughly constant from year to year, but those for PL decreased progressively in magnitude from 1998 to 2000. Examination of a small number of hatcheries in 2000 revealed that the percentage of WSSV-positive PL samples was significantly lower for hatcheries that routinely discarded WSSV-PCR-positive wild broodstock when compared to hatcheries that did not
\end{abstract}

KEY WORDS: WSSV - White spot syndrome virus · Prevalence $\cdot$ Broodstock $\cdot$ Post-larvae

Resale or republication not permitted without written consent of the publisher

White spot disease (WSD) caused by white spot syndrome virus (WSSV) has affected farmed penaeid shrimp worldwide. Susceptible species include Penaeus monodon, $P$. vannamei, $P$. stylirostris, $P$. japonicus, $P$. chinensis ( $P$. orientalis), $P$. indicus, $P$. merguiensis, $P$. setiferus and $P$. penicillatus (Flegel 1997, 2001). The disease has led to epizootics and significant production losses in numerous countries in both the eastern and western hemispheres (Flegel 1997, Lightner et al. 1997, Nunan et al. 1998). Although Thailand had its first WSD outbreaks in 1995 (Flegel 1997) and still suffers from them, it has managed to maintain its status as the world's leading cultured shrimp producer for the past several years. The reason for this success is not definitely known, but could be due to one or more of the following factors. First, the Thai shrimp farming industry consists predominantly of low-investment small-scale farms which allow many farmers to start new crops after a previous failure. Second, farmers are eager to apply new technologies developed and recommended by researchers, in the hope of obtaining successful crops. Third, many Thai farmers employ closed culture systems to prevent WSSV carriers from entering their cultivation ponds. Fourth, many also use sensitive PCR detection services to screen out normallooking but WSSV-infected $P$. monodon post-larvae (PL) before stocking their ponds. Fifth, many farmers have learned from experience to avoid stocking their shrimp ponds during the winter monsoon season (beginning in October and lasting $3 \mathrm{mo}$ ), because WSD outbreaks are known to occur more frequently then. The monsoons bring SW winds and storms to the southern part of Thailand, where most of the wild broodstock are captured.

Wild Penaeus monodon broodstock are captured live by Thai fishermen as an adjunct to normal fishing activities. They subsequently use radio communication to inform brokers with high-speed boats who collect the captured shrimp for distribution to shrimp hatchery operators. In routine hatchery practice, wild broodstock are acclimatized for one or more days before being unilaterally eyestalk-ablated. After that, ovarian development commences and reaches Stage 4 (maturity) within 4 to $5 \mathrm{~d}$ before spawning. Some hatcheries send the ablated eyestalks (minus the eye), cut pieces of swimming legs (pleopods) or haemolymph samples 
to service laboratories for WSSV-PCR testing. Ideally, samples for testing should be taken after the first spawning to improve the chances of detecting positive specimens (Hsu et al. 1999). For WSSV-PCR tests of PL, farmers usually send samples of 30 to 50 pooled PL12 to PL15 to service laboratories and they reject batches that are PCR-positive for WSSV for stocking ponds. According to veterinary sampling tables (Lightner 1996) this would give a $95 \%$ probability of detecting WSSV at a prevalence of approximately 5 to $10 \%$.

This work examines PCR test results for WSSV using samples of wild broodstock and PL collected continuously from 1998 to 2000. The objective was to determine whether there were any consistent fluctuations in percentage of positives that might explain the high incidence of WSD outbreaks in shrimp ponds during the winter season in Thailand. Since some hatcheries have employed PCR to screen out WSSV-infected wild broodstock during the past few years, we also compared the prevalence of WSSV infection in the PL produced from hatcheries that did and did not carry out this practice.

Materials and methods. There are approximately 30 laboratories in Thailand that provide PCR screening services to shrimp farmers. For this study, data were collected continuously over 3 yr (1998 to 2000) from 8 private laboratories that provided WSSV-PCR screening services for Penaeus monodon wild broodstock and PL. All these laboratories employed the same primers and same protocol for a single-step PCR for WSSV based on a WSSV-specific DNA fragment described by Wongteerasupaya et al. (1996). Two laboratories were located on the east coast of the Gulf of Thailand and 6 on the east and west coasts of the south of Thailand. These locations roughly spanned all areas of the country where $P$. monodon is cultured. Since the samples comprised shrimp brought to the laboratories by customers, they could have been biased in unknown ways. For example, it is possible that the farmers who bring shrimp for sampling do not represent a random sub-set of all farmers, and that the broodstock and brooders they bring for sampling do not represent random sub-sets of their respective populations. This means that any extrapolation from WSSV prevalence in these samples to WSSV in natural populations of broodstock and shrimp must be made with caution.

The sampling processes and procedures for PCR were carried out as previously described (Withyachumnarnkul 1999) using a WSSV-PCR kit and protocol obtained from the Shrimp Biotechnology Business Unit, National Center for Genetic Engineering and Biotechnology, Bangkok, Thailand. Briefly, eyestalks, pleopods or PL fixed in $95 \%$ ethanol were homogenized with $0.5 \mathrm{ml}$ lobster haemolymph buffer (LHB), boiled at $100^{\circ} \mathrm{C}$ for $10 \mathrm{~min}$ and centrifuged at $4000 \times \mathrm{g}$ for $5 \mathrm{~min}$ at room temperature before $5 \mu \mathrm{l}$ of the supernatant was used as the PCR template. Compound eyes were cut off from eyestalks before fixing in ethanol, as certain components in them have been reported to inhibit the PCR reaction (Lo et al. 1997). Samples were added to $50 \mu \mathrm{l}$ of the PCR reaction mixture and the reaction was carried out for 35 cycles comprising denaturation $\left(90^{\circ} \mathrm{C}\right.$ for $\left.3 \mathrm{~min}\right)$, annealing $\left(60^{\circ} \mathrm{C}\right.$ for $\left.30 \mathrm{~s}\right)$ and polymerization $\left(72^{\circ} \mathrm{C}\right.$ for $\left.30 \mathrm{~s}\right)$ as recommended in the kit instructions. The kit primers yielded a $232 \mathrm{bp}$ fragment specific for WSSV DNA that was detected by $1.5 \%$ agarose gel electrophoresis of $20 \mu \mathrm{l}$ aliquots.

In the year 2000, the mean prevalence of WSSV-PCR-positive PL from 3 hatcheries that used PCR to eliminate WSSV-infected broodstock and their offspring was compared to that from 5 traditional hatcheries that did not use the screening method. Monthly prevalence values were calculated as the proportion of PL batches that were positive each month across all 8 hatcheries. Mean monthly prevalence for each year was calculated from these values and given as the monthly mean each year $\pm 1 \mathrm{SD}$. Overall means for 3 years were calculated using the yearly means, and were expressed as means \pm SE. Statistical analyses were done using SigmaStat computer software (Version 2, Jandel). For multiple comparisons, a 1-way analysis of variance (ANOVA) was used combined with a Student-Newman-Keuls test to isolate the significantly different groups. For paired comparisons a $t$ test was used. For the paired data in Fig. 4, the normality test failed, so a Mann-Whitney rank sum test was carried out instead.

Results. For individual months from 1998 to 2000, there was wide variation in the number of wild broodstock specimens (202 to 1280) and PL batches (909 to 3493) that were tested for WSSV. For the broodstock, the 3 yr mean number tested per month was $676 \mathrm{SE} \pm$ 151 (lowest mean 419 and highest 1029) while the $3 \mathrm{yr}$ mean number of PL batches tested per month was 2264 $\mathrm{SE} \pm 340$ (lowest mean 1828 and highest 2751). Presented in another way, the total number of broodstock tested was 7521 (1998), 6440 (1999) and 10377 (2000) with a yearly mean of $8113 \mathrm{SD} \pm 2034$, while the total number of PL samples tested was 22226 (1998), 31011 (1999) and 27172 (2000) with a yearly mean of 27172 $\mathrm{SD} \pm 4469$. The mean monthly number of broodstock tested in 2000 (865) was significantly higher $(\mathrm{p}<0.05)$ than in 1998 (627) and 1999 (537); however, there were no significant differences in the mean monthly number of PL batches tested for the 3 years.

In general, the monthly proportion of WSSV-positive broodstock and PL samples varied greatly (Fig. 1), but the overall, 3 yr mean monthly prevalence was 5.1 SE $\pm 4.9 \%$ and $4.8 \mathrm{SE} \pm 3.0 \%$, respectively, and the difference between the 2 was not significant ( $p=0.81$ ). The 


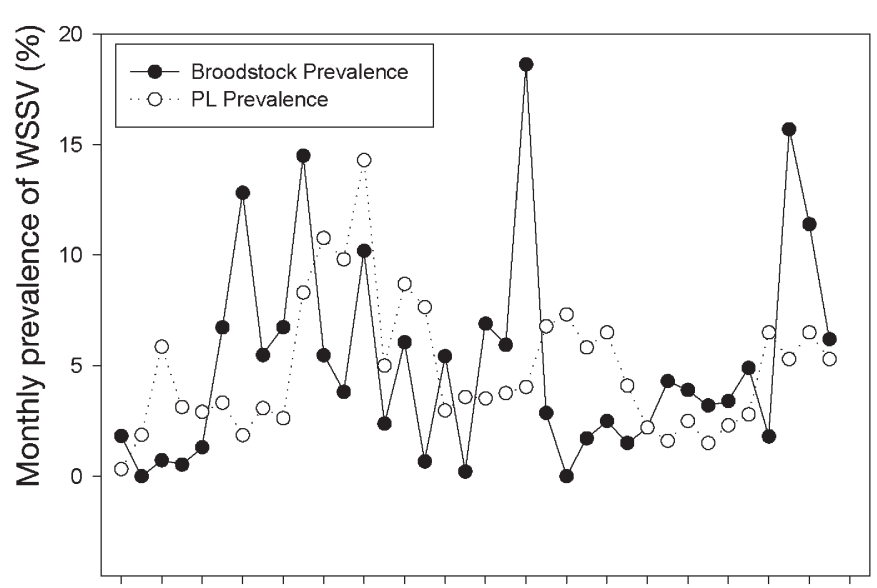

Jan Mar May Jul Sep Nov Jan Mar May Jul Sep Nov Jan Mar May Jul Sep Nov Jan 1998

1999

2000

Fig. 1. White spot syndrome virus (WSSV) prevalence in broodstock and post-larvae (PL) as determined by PCR analysis over $3 \mathrm{yr}$

mean monthly prevalences on a yearly basis from 1998 to 2000 for broodstock were also very close to $5 \%$, while those for the PL ranged from 3.9 to $6.1 \%$. None of these differences was statistically significant. The highest and lowest prevalences for a single month over the 3 yr period were 0 and $18.6 \%$ for the broodstock and 0.3 and $10.8 \%$ for the PL. For both broodstock and $\mathrm{PL}$, prevalence was generally low during the mid-part of the year and high during the end of the year through to the early part of the following year (Fig. 1). This trend was even more apparent when mean monthly averages for 3 years were graphed (Fig. 2). In addition, the graph showed that the increase in WSSV prevalence in the PL followed after that of the broodstock. Based on this result, a further analysis was carried out to determine whether there was a statistical correlation between WSSV prevalence in the broodstock and PL. This was done using 3 mo rolling averages for the monthly broodstock and PL prevalence values over the whole 3 yr period of the study. Using this method, there was no significant correlation between WSSV prevalence in broodstock and PL when monthly averages for the 2 were directly compared. However, when a 1 mo lag was inserted for pairing the PL values, a significant $(\mathrm{p}<<0.01)$ positive correlation was found with a correlation coefficient of 0.56 . By increasing the lag period, the correlation coefficient increased steadily to a maximum value of 0.67 (Fig. 3) for a 3 mo lag. With a 4 mo lag, it dropped again dramatically.

In the year 2000, the mean prevalence for WSSV in PL from 3 hatcheries that practiced PCR screening was compared to that from 5 hatcheries that did not. A significantly lower prevalence $(p<0.001)$ was found for the practicing hatcheries (Fig. 4 ) with 8 mo of $0 \%, 3$ mo

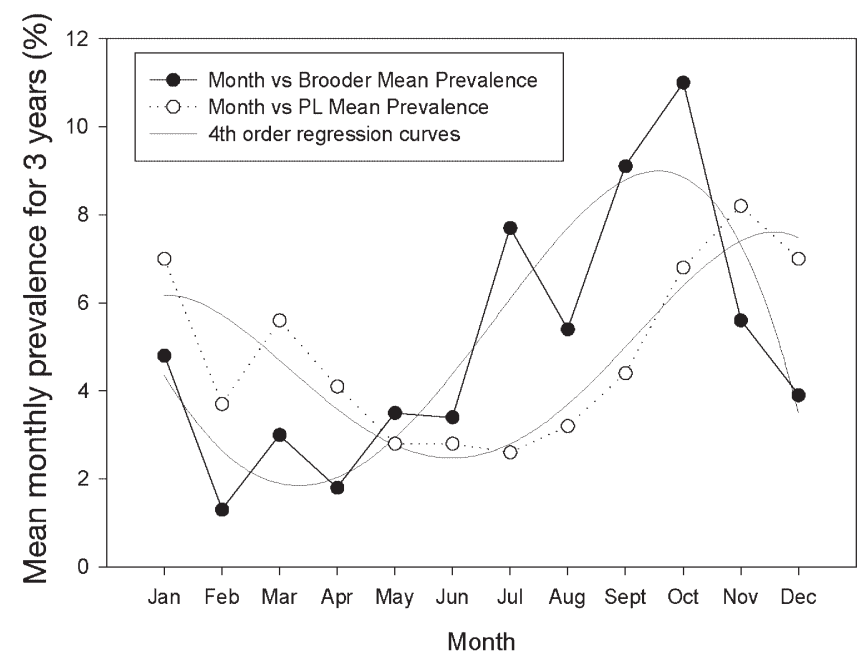

Fig. 2. Mean monthly averages for $3 \mathrm{yr}$ calculated from the data in Fig. 1. This is shown together with 4th-order regression curves, both indicating a general annual fluctuation in WSSV prevalence with a lag in the values for the post-larvae (PL) when compared to those for the broodstock. Data were plotted with 4th-order regression lines using SigmaPlot computer software (Version 5, Jandel)

of less than $2 \%$ and 1 mo of $4 \%$ prevalence. By contrast, prevalence in the non-practicing hatcheries ranged from 2 to $8 \%$.

Discussion. We found that the mean prevalence of WSSV-positive samples for wild broodstock and PL batches in Thailand over 3 yr was the same and relatively low at about $5 \%$. It is difficult to estimate how indicative these data are for the whole country. Although no direct figures are available, the total number of wild female broodstock and PL required to supply the Thai shrimp industry yearly can be estimated by back calculation based on the amount of cultured Penaeus monodon harvested (approximately $250000 \mathrm{t}$ $\mathrm{yr}^{-1}$ ). At an average size of $25 \mathrm{~g}_{\text {piece }}^{-1}$ or $40 \mathrm{~kg}^{-1}$, this would amount to approximately 10 billion shrimp. With an average survival of $60 \%$, this would translate into a requirement for approximately 17 billion PL, not counting the failures in cultivation. The average production from 1 pond is approximately $3 \mathrm{t}$, accounting for approximately $200000 \mathrm{PL}$ as the rough amount for 1 stocked batch that might be tested for WSSV by PCR. Thus, we might estimate about 85000 stocked batches $\mathrm{yr}^{-1}$. Considering that 1 female broodstock produces an average of $300000 \mathrm{PL}$, we come up with a minimum of approximately 57000 to supply the Thai shrimp industry for $1 \mathrm{yr}$. Using these numbers and our average yearly number of 8113 , tested broodstock might account for about $17 \%$ of the total broodstock used in the country, and it may not accurately reflect the national prevalence of WSSV infection in broodstock used by all hatcheries. Estimation of national WSSV 


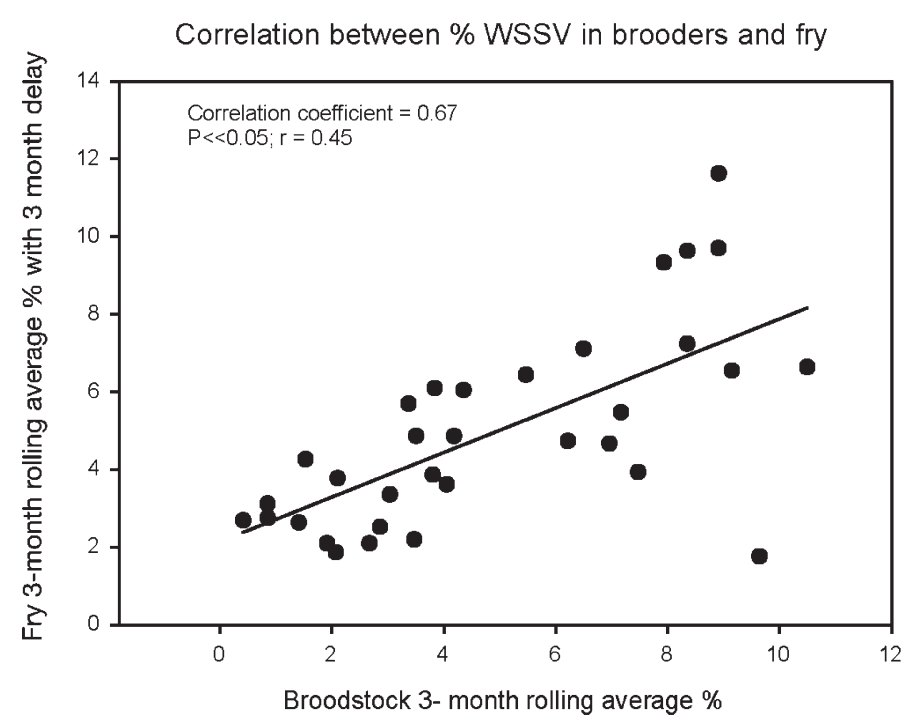

Fig. 3. Correlation between mean WSSV prevalence in broodstock and post-larvae (PL) over the $3 \mathrm{yr}$ period of the study. For the graph shown, 3 mo rolling averages of prevalence were used and the broodstock average for any month was paired with the PL average 3 mo later (i.e. a 3 mo lag was inserted). This gave a higher correlation coefficient and linear correlation coefficient than comparisons made with no lag or lags of 1, 2 or 4 mo. Because of the 3 mo lag, there are 33 instead of 36 data points in the graph. A Pearson correlation test was used and the data were plotted with a linear regression line using SigmaPlot computer software (Version 5, Jandel)

prevalence for PL is more difficult since there is a high possibility that 2 or more tested samples might have originated from the same nursery tank. On the other hand, our yearly mean of approximately 27000 tested PL batches indicates that the use of PCR testing is high, especially since we had data from less than half of the total number of PCR laboratories in the country.

If an estimate of $5 \%$ WSSV prevalence in 57000 broodstock were correct, discarding all positive broodstock from production lines would cost approximately US\$ $570000 \mathrm{yr}^{-1}$, at an estimated price of US\$ 200 per broodstock female. By contrast, discarding $5 \%$ of 17 billion PL valued at US\$ 0.0033 per PL would cost approximately \$US 2.8 million. Thus, it would be much more cost-effective to concentrate on eliminating WSSV-infected broodstock and their larvae at the hatchery.

It is not known why the prevalence of WSSV infection was high at the end of the year through to the early period of the following year. However, this interval generally covers the cool monsoon season with frequent storms and heavy rainfall in the southern part of Thailand, where the majority of wild broodstock are captured. It is possible that strong currents may force the broodstock to aggregate in certain 'safe' areas, causing population congestion and therefore increas-

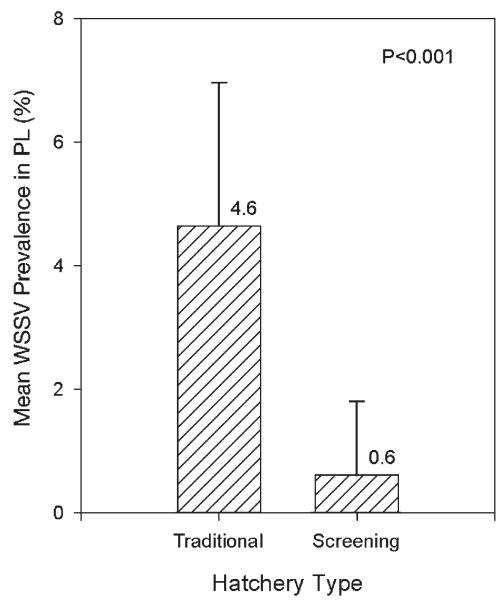

Fig. 4. Prevalence of WSSV positive $\mathrm{PL}$ produced in 2000 by 5 traditional hatcheries without WSSV screening and by 3 non-traditional hatcheries where WSSV screen-out procedures were used

ing the chance of horizontal transmission of WSSV. Another possibility is that colder water temperatures may, by some unknown mechanism, enhance replication of the virus, as has been reported for WSSV infection in Penaeus vannamei (Vidal et al. 2001). Yet another possible explanation is that fishermen are confined to shallow (e.g. 10 to $20 \mathrm{~m}$ depth) inshore waters during the monsoon season and cannot capture broodstock from deeper waters (e.g. 50 to $70 \mathrm{~m}$ depth). Such inshore broodstock populations might contain large numbers of escapees or discards from shrimp farms and might therefore have a higher prevalence of WSSV. Lo et al. (1997) also reported that there was seasonal variation in WSSV prevalence in captured Penaeus monodon female brooders from Taiwan, but the trend was the opposite to that seen here in that prevalence was highest from August to November and lowest from December to February. On the other hand, the number of specimens examined in that study was relatively small (48), and therefore statistical comparisons were not possible.

We have no firm explanation for the high positive correlation between the prevalence of WSSV in brooders and the prevalence in PL 1 to 3 mo later. We were surprised neither by the lack of significant correlation between these values for the same month nor the highly significant correlation ( $p<<0.01$ ) with a 1 mo delay for the PL. This is because broodstock specimens are eyestalk-ablated and usually spawn within $1 \mathrm{wk}$, leading to marketable PL15 approximately $21 \mathrm{~d}$ later (i.e. a total of $28 \mathrm{~d}$ ). In addition, earlier publications have suggested that WSSV infection is spread to farms through vertical transmission of virus from brooders via PL (Mohan et al. 1997, Hsu et al. 1999, Withyachumnarnkul 1999, Kasornchandra et al. 2000). However, we were surprised to find that the correlation coefficient was highest for a 3 mo lag between broodstock and PL prevalence values. The reason for this is unknown, but there are some possibilities that should 
be further investigated. First, it is possible that the mean time to spawning for broodstock specimens after ablation and the time taken to obtain marketable PL15 are much longer than generally thought. It is also possible that spawners are held to spawn several times over a period of weeks and that the probability of them producing WSSV-positive PL is higher with later spawns.

In conclusion, the interval of peak WSSV prevalence in the brooders and PL did correspond to the cool season peak in WSSV outbreaks on shrimp farms in Thailand, supporting previous work that showed WSSVinfected PL can lead to pond outbreaks of WSD (Withyachumnarnkul 2001). In the interval before specific pathogen-free domesticated broodstock of Peneaus monodon become available, it is necessary to minimize the entry of pathogens into the shrimp production system via captured brooders. One approach is to rigorously screen them for pathogens and eliminate infected individuals and their offspring at the hatchery; we found that this practice lowered the prevalence of WSSV contaminated PL by approximately 8 times. In addition, the study results suggest that it might be useful to determine whether the observed seasonal variation in WSSV prevalence is related to broodstock acquisition or handling procedures that might be changed to further reduce the risk of introducing WSSV into the farming system.

Acknowledgements. This work was partially supported by the National Fisheries Institute of the United States of America, Arlington, VA.

\section{LITERATURE CITED}

Flegel TW (1997) Major viral diseases of the black tiger prawn (Penaeus monodon). World J Microbiol Biotechnol 13(4):433-442

Flegel TW (2001) The shrimp response to viral pathogens. In: Browdy CL, Jory DE (eds) The new wave. Proc Special Session on Sustainable Shrimp Aquaculture, World Aquaculture 2001, Orlando. World Aquaculture Society, Boca Raton, FL, p 190-214

Hsu HC, Lo CF, Lin SC, Liu KF and 5 others (1999) Studies on

Editorial responsibility: Chris Baldock,

Brisbane, Queensland, Australia effective PCR screening strategies for white spot syndrome virus (WSSV) detection in Penaeus monodon brooders. Dis Aquat Org 39:13-19

Kanchanaphum P, Wongteerasupaya C, Sitidilokratana N, Boonsaeng V, Panyim S, Tassanakajon A, Withyachumnarnkul B, Flegel TW (1998) Experimental transmission of white spot syndrome virus (WSSV) from crabs to shrimp Penaeus monodon. Dis Aquat Org 34:1-7

Kasornchandra J, Tandavanith S, Kongpradit R, Sriwatanavaranyou S (1999) The possibility of vertical transmission of white-spot syndrome virus on Penaeus monodon. Proc 2nd Natl Symp Marine Shrimp. National Center for Genetic Engineering and Biotechnology, Bangkok, p 32-41 (in Thai)

Kiatpathomchai W, Boonsaeng V, Tassanakajon A, Wongteerasupaya C, Jitrapakdee S, Panyim S (2001) A nonstop, single-tube, semi-nested PCR technique for grading the severity of white spot syndrome virus infections in Penaeus monodon. Dis Aquat Org 47:235-239

Lightner DV (1996) Handbook of pathology and diagnostic procedures for diseases of penaeid shrimp. World Aquaculture Society, Baton Rouge, LA

Lightner DV, Redman RM, Poulos BT, Nunan LM, Mari JL, Hasson KW (1997) Risk of spread of penaeid shrimp viruses in the Americas by the international movement of live and frozen shrimp. Rev Sci Tech Off Int Epiz 16(1): $146-160$

Lo CF, Ho CH, Chen $\mathrm{CH}$, Liu KF and 9 others (1997) Detection and tissue tropism of white-spot syndrome baculovirus (WSBV) in captured brooders of Penaeus monodon with a special emphasis on reproductive organs. Dis Aquat Org 30(1):53-72

Mohan CV, Sudha PM, Shankar KM, Hegde A (1997) Vertical transmission of white spot baculovirus in shrimp - a possibility. Curr Sci 73(2):109-110

Nunan LM, Poulos BT, Lightner DV (1998) The detection of white spot syndrome virus (WSSV) and yellow head virus (YHV) in imported commodity shrimp. Aquaculture 160(1-2):19-30

Vidal OM, Granja CB, Aranguren F, Brock JA, Salazar M (2001) A profound effect of hyperthermia on survival of Litopenaeus vannamei juveniles infected with white spot syndrome virus. J World Aquacult Soc 32:364-372

Withyachumnarnkul B (1999) Results from black tiger shrimp Penaeus monodon culture ponds stocked with postlarvae PCR-positive or -negative for white-spot syndrome virus (WSSV). Dis Aquat Org 39:21-27

Wongteerasupaya C, Wongwisansri S, Boonsaeng V, Panyim S, Pratanpipat P, Nash GL, Withyachumnarnkul B, Flegel TW (1996) DNA fragment of Penaeus monodon baculovirus PmNOBII gives positive in situ hybridization with viral infections in 6 penaeid shrimp species. Aquaculture 143:23-32

Submitted: August 19, 2002; Accepted: October 21, 2002 Proofs received from author(s): January 20, 2003 